\title{
Central Europe Within the European Union
}

\author{
Prof. Iván BÁBA PhD
}

\begin{abstract}
The trauma of World War II led the best European politicians of the postwar era to the insight that future wars in Europe could be avoided through eliminating any potential of military conflict. Seventy years have passed since then, and the world, including Europe, has changed. Currently the Brexit and international migration are a big challenges for Europe. The historical experiences of peoples in Central Europe, the series of events in the past two hundred years fundamentally define the "perception of security" within these communities. This sense of and demand for security in turn have a key role in forging and shaping the international relations of countries within our region. Unsurprisingly, in 1990, the year when communism collapsed in Central Europe, freed from Soviet rule, almost all newly formed democratic governments designated NATO membership as a guarantee of their security. They strove to join a federal system which would allow them to rely on the same guarantees of security as did Western European countries. The member states of the European Union accelerated negotiations on more and more frequently raised issues of a common foreign and security policy. In a geopolitical sense - and in terms of its historical experiences - Central Europe is located within the Berlin - Moscow - Istanbul triangle, which is an unalterable status. Berlin is an ally and our biggest, key economic partner. It is in our interest to have good partnership relations with Moscow, but we must be aware that Russian politics has always been - and will be - driven by imperial interest. As a NATO member, Turkey is also our ally, but the steps it took in recent years, in both domestic and foreign policies, were by no means evidence of a friendly attitude towards and the commitment of an ally to the West. Turkey begins to emerge as one of the leading countries of the Islamic world, gradually leaving behind the domestic policy of a secular state. Therefore Central Europe - forming the eastmost part of the European Union - borders all the eastern and south-eastern regions which carry security risks. The wave of migrants from the south and south-east keeps these regions, Greece and her northern neighbours under constant pressure. Another grave risk factor is the Union's eastern borderland, that is, the region next to the eastern boundary of the Baltics, Poland, Slovakia, Hungary and Romania. As geopolitical factors, Russia, Ukraine and Belarus are not the carriers of democratic stability. Although Central Europe's geopolitical position cannot be changed, common European and Euro-Atlantic security safeguards may guarantee defence in this position.
\end{abstract}

\section{Keywords}

alliance, Central Europe, European Union, international relations, security 


\section{"Finalité politique"}

The trauma of World War II led the best European politicians of the postwar era - Konrad Adenauer, Robert Schuman and Alcide De Gasperi - to the insight that future wars in Europe could be avoided through eliminating any potential of military conflict. By creating the European Coal and Steel Community (ECSC), French and German coal and steel industries were subjected to community-level, supranational supervision in order to prevent heavy armaments production from being restarted within national frameworks. As the first supranational European institution and a distant precursor of the current European Union, the main function of ECSC was to provide an enduring guarantee of peace and security in Europe. Although apparently ECSC had been created as an economic agreement, it was originally designed to establish political unity.

Seventy years have passed since then, and the world, including Europe, has changed. While Europe succeeded in establishing its internal peace, global risks - ncreasing social inequalities in several parts of the world, nuclear threat, climate change, accelerated population growth and mass migration, difficulties of access to water, food and energy - pose an extremely great challenge for Europe, the most affluent and most secure region in the world. Today it is a question of utmost importance whether Europe will be able to respond to these challenges and, if yes, what kind of response it would be.

In one of his essays, Hungary's former Minister of Foreign Affairs János Martonyi evaluates the current situation as follows:

"We are falling behind in two areas that determine, particularly in the longer term, historical development. These two fields are demography and technology. In the first, we have a shrinking population, in the second, we are lagging. Both are basically dependent on culture, since it is our own choice that determines how we aim to reproduce ourselves, individually and collectively, and we also have to make up our minds if we want to invent new things and, if yes, what we are going to do to this end. Now, culture encompasses and defines our patterns of cognition and behaviour, being inseparable from what we can briefly describe as collective identity.

Hence, we reach the gravest challenge of European integration, which derives from this process itself rather than from the outside: the lack of balance which should exist, on the one hand, between the economic and political dimensions, and these two and the cultural dimension on the other. The initial end goal of integration (finalité politique) was to create political unity, but over time the political dimension and its external representation in the form of common foreign, security and defence policies had been subdued by the otherwise spectacularly successful economic dimension. However, the real trouble was the neglect of the cultural dimension mainly because of insensitivity or, in fact, mistrust towards European identity as the most important form of collective identity, preceded only by national identity. A possible reason for this could be the very ideological aversion to national identity which cast its shadow on other categories of collective identity, among them European identity. By this time it has become obvious that national identity and European identity are interdependent, none of them can be robust without the other. National identity provides the strongest sense of collective self-identity and serves as a basis for European identity. It is a noteworthy phenomenon that, due to historical reasons, 
the sense of belonging to Europe or even the European Union is the strongest in countries where the sentiment of nationality is also particularly strong - in Poland and Hungary. Here, in the stormier part of Europe, we had to fight back against external attacks which equally threatened our national and European existence, and the stake of preserving both identities was the persistence, survival of our national community.

Therefore the first and foremost condition of rethinking, and preserving through renewal, European integration is to reinstate the balance among the three major dimensions outlined by the original objectives. The realization of the political goal, also in relation to strengthening, as parts of external action, common foreign, security and defence policies is a task that can be fulfilled in the foreseeable future. External challenges and threats themselves are bound to render this necessary at least in part, this fact has been recognised. It has become clear that the successful provision of peace among member states, the 'peace dividend' does not protect them from external threats and potential attacks; apparently, it is not an enduring solution that Europe has to rely on others to ensure its security. The relative loss of economic and geopolitical ground and especially the demographic decline our continent has suffered further increase external risks and put the issue of security in the focus of the integration process. The habitat of European peoples must be protected, thus the necessary security conditions and defence capabilities must be established. However, territory and its protection do not constitute an end in itself, they mean much more than preserving the resources provided by a specific area. The third, so-called cultural dimension, European identity must also be protected. We have to acknowledge the existence and role of this dimension, and engage in a reasonable debate on its content. This debate will demonstrate that we prioritize different features from among the constitutive elements of European identity. Some of us may deem Greek antiquity, the Renaissance or the Enlightenment to be the most important, for others, it is the Judeo-Christian religious and cultural heritage. Our choices of priority differ, but this does not change the essence of European identity." 1

\section{Central Europe's security}

\section{What is security?}

According to the definition given in related literature, the concept of security means the "non-existence" of danger and threat on the one hand, and the capability of fending off danger and threat on the other. Functioning within a system of international relations, a state aims to shape its security environment to its advantage and enforce its interests, while it also prepares for and averts external challenges, emerging risks and threats. The lack of security means that a situation carries threat to existence, whose management requires taking extreme measures.

Literature highlights that, to a significant degree, security is a perceptual issue. What an individual and a community think or believe about their own security is determined by both the objective security situation and subjective sense of security (even of a collective

1 János Martonyi, Nyitás és identitás - Geopolitika, világkereskedelem, Európa [Opening and Identity: Geopolitics, World Trade, Europe] (Szeged: lurisperitus Kiadó, 2018), 15-16. 
as a whole) or perception. Different states, nations and other communities quite often have utterly different views or senses of how serious the same threat is. Factors threatening security are usually categorized by their intensity, describing them as a challenge, risk, threat or, in worse cases, crisis, conflict and war.

"Challenge" means a situation or state which may have a lasting and harmful influence on security in general, including, for example, the implications of demographic explosion, the scarcity and unequal distribution of energy sources and water, food and natural resources, as well as environmental problems. "Risk" denotes the potential of a harmful event with predictable outcomes that impact a given community. Whenever such an event occurs, collective interests are hurt and losses may emerge. These phenomena include massive and illegal migration, religious fanaticism, extreme nationalism and illegal arms trafficking. "Threat" is a general term for situations, states and processes that manifest at the highest level of potential danger. The origin, aim and intensity of threat can all be defined. For a state, threat can be, for example, a range of acts related to organized crime and terrorism, rise in violent radicalism or the emergence of a grave political crisis in its neighbourhood.

\section{What are the distinctive features of security perception in Central Europe?}

The historical experiences of peoples in Central Europe, the series of events in the past two hundred years fundamentally define the "perception of security" within these communities. This sense of and demand for security in turn have a key role in forging and shaping the international relations of countries within our region.

During the last two hundred years, one of the most shocking collective political experiences for peoples of this region was that they could disappear from the map of Europe at any time as a cumulative result of the interplay among forces that they cannot control and, in fact, that can put an end to their existence as both a state and a nation.

Let us evoke some examples.

- Russia, Prussia and the Habsburg Monarchy gradually partitioned, and eventually divided among themselves, the Polish-Lithuanian Commonwealth in the period between 1772 and 1795. As a result, Poland and Lithuania had been missing from the map of Europe for 124 years.

- During the 1920 peace negotiations in Versailles, the Hungarian delegation had been allowed to sit at the negotiating table only after victorious powers decided on the fate of Hungary.

- On 30 September 1938, driven by the self-deceptive illusion of preserving peace, French Prime Minister Daladier and British Prime Minister Chamberlain made an agreement with Hitler and Mussolini in Munich on letting Germany annex Czechoslovakia's Sudetenland. No Czechoslovakian representative was invited to this negotiation. Czech society was appalled by the treachery of its allies, France and the United Kingdom.

- On 15 March 1939, Hitler marched into Prague and established the Protectorate of Bohemia and Moravia, abolishing Czechoslovakia as a state. 
- On 23 August 1939, Soviet-Russian and German Foreign Ministers Molotov and Ribbentrop made an agreement on the division of Central and Eastern Europe into spheres of interest. On 1 September, Germany, followed by the Soviet Union on 17 September, invaded Poland. Within two months, Poland had been erased from the map of Europe. In 1940, Estonia, Latvia and Lithuania also disappeared. Poland's Western allies made no steps to stop these events. French people took to the streets of Paris, protesters shouting, "We will not die for Danzig!"

- During the infamous Yalta Conference, held between 4 and 11 February 1945, representatives of the allied Western powers, British Prime Minister Churchill and US President Roosevelt acknowledged Stalin's claim that the Soviet Union could keep the territories "obtained" through the Molotov-Ribbentrop Pact. They agreed that the Soviet Union could also finalize the occupation of the Baltic states and Bessarabia, as well as Poland's "westward shift" of almost 300 kilometres.

- During the infamous negotiations held in Potsdam between 17 July and 2 August 1945, British Prime Minister Attlee, US President Truman and Stalin decided on Central Europe's fate-entirely in line with Soviet demands.

- In October 1956, exploiting the Soviet Union's assumed difficult situation, the United Kingdom and France triggered the Suez crisis, diverting attention from the victorious Hungarian revolution at a time when Hungary was in great need of the attention and active support of the international political publics.

These and numerous other frustrations and shocks left a deep and everlasting burn in the historical memory of Central European societies. Unsurprisingly, in 1990, the year when communism collapsed in Central Europe, freed from Soviet rule, almost all newly formed democratic governments designated NATO membership as a guarantee of their security. They strove to join a federal system which would allow them to rely on the same guarantees of security as did Western European countries.

However, here again, Central Europe was shocked by surprise. In October 2005 German Chancellor Gerhard Schröder swapped his chair with a single move for the chairmanship in the supervisory board of the consortium Nord Stream AG, majority-owned by Russian Gazprom. The investment project established a pipeline transporting energy directly between Russia and Germany through the Baltic Sea, bypassing Poland and other countries of the region. This action evoked rather bad memories in Polish public opinion, while other Central Europeans asked in a shock: how is it possible? Schröder was the Chancellor of the biggest EU member state and the biggest European country within NATO! Oddly enough, "officially" no-one asked the former German Chancellor what he carried with him, on data storage devices and in his mind, to his new office. 


\section{How was Central Europe's demand for security enforced during the political turn?}

President Mikhail Gorbachev had profoundly transformed the relationship between the Soviet Union and Central European countries. He made the decision of global strategic significance that the Brezhnev Doctrine-setting as a duty for all socialist countries to mutually provide military assistance-should be abolished and replaced with the basic political principle that socialist countries could identify for themselves the best methods in solving their economic as well as social problems.

Recognizing the danger posed by the then American "Star Wars" Strategic Defence Initiative, Gorbachev fundamentally changed world politics by first initiating, then implementing a considerable reduction of the huge US and Russian nuclear weapons arsenals. His steps derived partly from perceived necessity - that is, the acknowledgement of the fact that the United States was more advanced technologically - and partly from his own principles. For Gorbachev aimed to foster "humanistic relations" in foreign policy as well as in domestic affairs. He honestly believed in the potential "peaceful coexistence" of countries with different regimes, in a balance between cooperation and competition, the avoidability of war and the world-historical chances of socialism. He aimed to forge a balanced relationship with leaders of contemporary world politics - Ronald Reagan, George Bush, Helmut Kohl, Margaret Thatcher and François Mitterand - not because he wanted to introduce the Western social model in the Soviet Union, but because he wanted to save socialism and believed in the partnership of equals.

Caution on the part of then Hungarian politicians was induced by, rather than distrust of Gorbachev, the historical experience that, sooner or later, "radical reformers" were regularly ousted from power by counter-reformers in the Soviet Union. One of the most significant Hungarian promoters of the political turn, Imre Pozsgay, repeatedly cited the worrying question of this period in his memoirs: "Now, what if a Russian general goes wild?" These politicians were afraid of a military coup, the revolt of Russian generals who recognized the weakening of their positions. This revolt actually happened in August 1991 in the form of an attempted coup, but its participants were way too late.

Having been elected in 1990, the democratic leaders of Central Europe arrived in mainstream politics with historical experiences which urged them to take their countries, escaping from a political regime dictated by the Soviet Union, into Western security organizations as soon as possible.

In his government programme of May 1990, Prime Minister József Antall declared the fundamental theses of Hungary's new foreign policy, including "Euro-Atlantic integration," that is, accession to NATO and the European Community.

The fulfilment of such intent was not entirely free of risks, since at that time thousands of hundreds of Soviet soldiers were still stationed in Central Europe. In November 1990, József Antall sent emissaries carrying confidential messages to Warsaw and Prague. These diplomats were assigned to inform, strictly through spoken communication, high-level officials working at the foreign ministries of the receiving countries that "at the meeting of the Warsaw Pact Political Consultative Committee, to be held on 25 February 1991 
in Budapest, Hungary will exit the organization. What measures can be expected from Poland/Czechoslovakia then?" The foreign ministries of both countries promised quick responses, to be delivered through diplomatic channels. The responses arrived with content implying cooperation. The governments of Bulgaria and Romania were also informed, again, through diplomatic channels, about this joint intent and, when they declared their intention to exit too, all countries sent their collective message to Gorbachev. At the Budapest meeting of the Warsaw Pact Political Consultative Committee, the document on dissolving the military organization of the alliance had been signed, and on 1 July 1991 the Political Consultative Committee also ceased to exist. Thus the August coup in Moscow could result in a failed attempt only.

After the dissolution of the Warsaw Pact, the question whether Hungary and the rest of Central European countries should choose the road of neutrality, gaining an international status similar to, for instance, that of Austria, could have remained open. But the then dominant political parties and organizations did not propose this path in any of the respective countries. Rather, they decided to follow the road to Western integration, the accession to NATO and the EU. The intention underlying this ambition was clear. Central Europe was seeking a security system and allies ensuring regional security. It had an important, historically determined, common goal: to have a seat at the negotiating table where its fate would be decided. Central Europe wanted to make sure that no-one could decide about it in its absence.

This shared "subjective" demand for security was "objectivized" on 12 March 1999, when the foreign ministers of the first three Central European countries - the Czech Republic, Hungary and Poland - signed the North Atlantic Treaty.

\section{What kind of safeguards does the North Atlantic Treaty offer?}

The North Atlantic Treaty Organization (NATO) is a political and military alliance comprised of initially twelve and currently thirty European and North American countries. NATO's aim is to safeguard, by political and military means, the freedom and security of all member states in accordance with the North Atlantic Treaty and the principles of the Charter of the United Nations. The Treaty also defines the transatlantic link by which the security of the United States and Canada is tied to the security of Europe.

According to the Treaty, NATO serves as the basis for Euro-Atlantic security, providing mutual assistance for members of the alliance to counter military aggression, or the threat of such an action, against any member state. The essential basic principle of NATO, the indivisible security of the alliance, rests on shared commitment and cooperation among sovereign states. Solidarity and cohesion within the alliance ensures that none of its members has to face considerable security challenges alone, relying exclusively on its own national efforts.

The key components of the Treaty are:

- Article 3: Member states will continually maintain and develop their individual and collective capacity to resist armed attack, that is, enhance national military capabilities and the ability to conduct joint operations (interoperability). 
- Article 4: Members of the alliance will have a collective discussion about a necessary alliance response whenever, in the opinion of any of them, the security of any member is endangered by some external threat (consultation).

- Article 5: An armed attack against any member state shall be considered an attack against all members, and they will, in exercise of the right to individual or collective self-defence recognised by Article 51 of the Charter of the United Nations, take action in concert to protect the attacked member state (collective defence).

- Article 10: Member states may, by unanimous agreement, invite any other European state in a position to contribute to the security of the North Atlantic area (enlargement).

\section{How did the common foreign, security and defence policy of the European Union come to be, and where is it now?}

As a result of regime change in Central Europe, the disintegration of the Soviet Union and the Yugoslav wars, that is, the geopolitical transformation of the European region, the member states of the European Union accelerated negotiations on more and more frequently raised issues of a common foreign and security policy.

The starting point for a European foreign, security and defence policy, as articulated in an agreement, manifested in the Maastricht Treaty (effective on 1 November 1993) which, besides establishing an institutionalized common foreign and security policy, envisioned potential European cooperation in the field of defence that pointed towards common defence. According to the treaty, "The common foreign and security policy shall include all questions related to the security of the Union, including the eventual framing of a common defence policy, which might in time lead to a common defence."

The next step was taken at the Franco-British negotiations in St. Malo (3-4 December 1998), producing a joint declaration which set the following objectives:

- The conditions of the European Union's capacity for autonomous action on the international stage must be created through providing for the necessary credible military forces and an effective decision-making mechanism to use them.

- Europe needs strengthened armed forces which can react rapidly to the new risks, and which are supported by a strong and competitive European defence industry and technology.

The Helsinki EU summit of December 1999 formally identified the task of European security and defence policy, defined the size of necessary military capabilities and laid the foundation for an institutional background. Subsequently, operational arrangements which would allow non-EU member European NATO members to participate in European Union operations were determined. It had been declared that, whenever an EU-launched crisis management operation required recourse to NATO assets, non-EU member NATO members and EU candidate countries would be invited to take part. As to cooperation between the EU and NATO, the so-called Berlin Plus agreement, signed on 17 March 2003 in Brussels, constituted a milestone. This agreement aimed to eliminate unnecessary parallelisms in resources by allowing EU access to NATO's operational capabilities. Its arrangements ensured that EU-led operations could rely on NATO's European headquarters 
that NATO's defence planning system would be transformed in order to incorporate EU needs. Moreover, procedures for monitoring the use of NATO assets had also been developed.

\section{What is the content of Europe's Common Security and Defence Policy?}

We can speak of Common Security and Defence Policy (CSDP) since the adoption of the Lisbon Treaty (13 December 2007). It covers all questions relating to EU security, including the progressive framing of a common defence policy that might lead to a common defence. The defence policy includes means to be used to manage new challenges which emerge in the territories of third countries rather than within the EU's area.

Although the cornerstone of collective defence is NATO, based on the "Mutual Assistance Clause" of the Lisbon Treaty, if an EU member state suffers armed aggression on its territory, the other members have an obligation of aid and assistance by all the means in their power. This clause does not prejudice the specific character of the security and defence policy of neutral member states, and it is consistent with commitments under NATO.

According to the "Solidarity Clause," if an EU member state becomes the object of a terrorist attack or the victim of a natural or man-made disaster, members shall act jointly to provide assistance "in a spirit of solidarity." In such a case, the Union shall mobilize all the instruments at its disposal, including the military resources made available by the member states.

In the framework of the Lisbon Treaty EU members also agreed on the establishment of "Permanent Structured Cooperation" (PESCO), adopted by twenty-five countries, among them Hungary, which took effect on 11 December 2017.

PESCO provides an opportunity, for member states that are willing and able to do so, to develop their defence capabilities and improve the operational capacities and contributions of their armed forces. The Council published, in its resolution establishing PESCO, the list of common commitments that participating countries undertook to fulfil, including a regular increase in the real value of defence expenditure in order to achieve jointly adopted objectives. One of the main objectives of PESCO is to harmonize the military capabilities and resources of participating member states.

\section{Brexit}

\section{Why did the United Kingdom leave the European Union?}

Divorce is normally dependent on both parties, and the same applies to political relations. As it is known, French politicians - namely, De Gaulle - as long as they could, constantly opposed and obstructed Britain's admission to the European Union, arguing that Brits had never been "whole-hearted" Europeans. They always considered Europe, the Continent, some external entity. 
This is by all means true. British political and public thinking retained this mindset, "exceptionalism," even after 1973, during the EU membership of the United Kingdom. To mention but a few examples, the UK stayed outside the European exchange rate mechanism (ERM) in 1979, succeeded in cutting its contributions to the EU budget through a correction mechanism (UK rebate), and opted out of both the Eurozone and the Schengen Area. We cannot ignore the fact that, as a legacy of the era when the UK was one of the leading countries of the world, a kind of superpower mentality survived that constantly prevented deeper involvement in European integration.

However, through political and institutional mistakes made over decades, the European Union and some of its states also contributed to the British departure. The "creeping extension" of European Commission competences, the lack of respect for treaties at EU institutions themselves, the "shifting" of political decision-making from the Council - as well as the European Council - to the Commission, the self-assertiveness and frequent political bias of some institutions, the disregard of national interests and member state jurisdiction drew aversion and objection among the British as well as in Central European member states. This significantly influenced the opinions, stances and, eventually, the decisions of Britain's political elite and, through this elite, of voting citizens.

Despite all of the above, one could ask why the referendum was necessary. Why did they hold a vote on whether the United Kingdom should leave the European Union? Today we know already that the referendum was based on then Prime Minister David Cameron's misperception of the situation. To offset pressure in home affairs, making an utterly unnecessary move in political terms, Cameron promised in 2013 that he would initiate a vote on whether Britain should stay in or leave the European Union if the Conservative Party won the 2015 general elections. As it is known from background conversations, he was convinced that the vote would have a "favourable" outcome, that is, it would bring about a majority of "remainers." During the referendum held on 23 June 2016 with a $72 \%$ turnout, $52 \%$ of participants voted for "leave" and $48 \%$ voted against it. Therefore approximately $38 \%$ of eligible voters decided that the United Kingdom must depart from the European Union.

\section{What are the geopolitical implications of the British exit?}

The European Union has lost its third most populous country, second largest economy and second largest contributor to its budget. As to security, it has lost one of the two EU nuclear powers, the strongest army and a permanent member of the UN Security Council. (From now on, the European Union is "represented" in the Security Council by France as a sole permanent member).

The geopolitical position of the European Union has changed. Obviously, the political leaders of the United Kingdom did not see through the exit process so that they could continue to conform to EU policies. Thus it is predictable that a new, distinct political pole will emerge on the western frontier of the European Union. This pole will act in its own best interests in terms of both European and global politics. It is a well-known saying, attributed to Lord Palmerston, that "England has no eternal friends ... only eternal and perpetual interests." This does not necessarily mean confrontation, but when 
it is placed on the "cooperative-competitive-confrontative" scale, used in the 1990s by political analysts to interpret Russian politics, the United Kingdom certainly moves from the cooperative position towards the competitive one, following exclusively its own security, economic and other interests. Consequently, in certain situations it will compete against the European Union.

\section{What kind of impacts and perceptions will Brexit have within the Union?}

How will it affect the internal cohesion of the EU? Will it strengthen the sense of union in EU public awareness, implying the need of closing ranks, or will it suggest that other members can leave the EU because "there is life outside the Union"?

With the British exit, our conception of Europe's security goes through a fundamental change. During the past fifty years the European Union experienced the age of continued "widening and deepening." Despite more or less intense internal debates, the history of the Union seemed to be a one-way success story. It was envisioned that the states of Europe would gradually converge in a great economic and political unity, providing peace, security and welfare for its citizens and protecting them from surges of an increasingly chaotic and perplexing world politics - and that this alliance would eventually integrate all Western, Central and Southern European states.

This image is now transformed. The British exit will certainly intensify professional and political debate on the future, operational and value system, internal cohesion and further enlargement of the Union. Proposals for the creation of a "European Federative State" will reappear, including some suggesting that states which do not embrace such proposals should be left behind. On the other side, this may again give rise to the idea that EU treaties should be thoroughly revised and renegotiated in order to reinforce the competences and sovereignty of member states.

Here again, János Martonyi's words should be quoted:

"Apart from structural-institutional consequences, there will be significant changes in the internal economic and geopolitical landscape. It is simple to sum up these changes: a shift eastwards, materializing primarily in a growing German interest in and reliance on Central Europe. This means that the economic and geopolitical weight of Central Europe will be on the rise, which will entail a greater political role as well as more responsibility. (A geopolitical upgrading of the region started well before the referendum, due to the new security risks created by Russia). This might be good news for the region, but non-euro member countries will not have the strongest voice when it comes to defending the interests and rights of the non-euro area, with special regard to the initiatives to use the euro-area as the faultline for an institutional split between the hard core and those outside it. ... The UK was also a natural ally of Central Europe in defending subsidiarity and national competences against the creeping extension of common competences of some of the EU institutions. A rebalancing between member states and EU institutions, as well as between the institutions themselves, will have to be achieved in the absence of an influential, albeit sometimes excessively self-propelled member state."2

2 Martonyi, Nyitás és identitás, 128-129. See also János Martonyi, "Brexit. Brexit?" Hungarian Review, Volume VIII, Nos. 3 and 4 (17 May and 19 July 2017). 
The reappearance of independent British politics on the stage of Europe will inevitably alter the European scenarios proposed so far and, to some extent, the cast of characters too. Brussels and London will constitute two distinct, rival poles-setting the scene for other European and non-European players.

The further development of EU security policy, including its military capabilities, remains an open question. Up to this point, the United Kingdom, arguing for the guarantees provided by NATO, has been the strongest opponent of building a more efficient European security and defence policy. Amidst Europe's shifting balance of power, we can again raise the question whether, within the framework of a Union working under the "strong influence" of Germany and France, an efficient common security and defence system will emerge which can provide EU member states with protection comparable to NATO security safeguards.

\section{Migration}

Migration has become an important and resounding issue in European politics, thus we cannot avoid its discussion either.

Being an intricate problem, migration should be scrutinized in a separate volume, and it already has literature that could fill a library. Yet its salience and direct political currency prompts us to outline our views on migration at this point.

In our opinion, migration has two fundamental causes: overpopulation and significant, enduring military conflicts. Mass migration towards Europe arrives, in somewhat simple terms, from three directions: from Africa, the Middle East and Central Asia. The main reason for migration originating in Africa and the Middle East is overpopulation, while inflows from Central Asia can be chiefly attributed to uncertainty, homelessness and lifethreatening conditions created by wars.

\section{What does the population explosion in Africa mean?}

Demographers began to issue warnings for political analysts and decision-makers about the dangers of demographic explosion, overpopulation in Africa decades ago. Since no notable intervention has been made, developments resulted in the current situation. Today Africa is the singular continent on our globe whose population overgrown in certain territories (habitats) practically exhausted the resources provided by nature and masses of millions moved or still moving towards other rural habitats or metropolitan areas. However, the scarcity of natural resources, primarily water - contrary to public belief - does not derive from a decrease in available water quantities, since no change has been recorded. (Planet Earth does not evaporate water into the universe)! Water scarcity derives from the ratio of the water base in a specific area to the population living in that area, or a change in this ratio. A certain quantity of water was enough for a certain size population over centuries or millennia, but it is not enough if that population goes through a five- or ten-fold growth. The same is applicable to any natural resource, soil or flora and fauna alike.

Another reason for the deterioration of nature is the greed and unscrupulous nature of big "Western" firms, the so-called transnational corporations. While in Europe 
or in the "advanced" world an investment usually has to conform to a range of strict construction rules and requirements relating to landscape or environment protection, which are designed to mitigate damages caused by the investment, protect both natural and built environment, and defend the interests of residents, in most countries of Africa these controls are weak, the government or local authorities of the given country have feeble self-defence capabilities, and their leaders are often corrupt. A giant multinational firm may possess much more power to enforce its interests than the self-defence capability of locals, and its aspiration - e.g. in the form of opening oil rigs or mines or large fisheries - often leads to the destruction of the natural environment and the expulsion of local populations from their ancient habitat.

Large-scale migration is a consequence of exhausting or destroying natural resources. In Africa tens of millions of people move, migrate from their traditional habitat to other areas, often to cities, in search of the minimum conditions of survival, of staying alive. However, this mode of "urbanization" obviously cannot help to resolve the problem. On the outskirts of large cities with millions of residents (in 2012 Lagos had 16 million, Kinshasa 13 million, Johannesburg 5.5 million, Dar-es-Salaam 4.3 million residents, respectively) slums emerge under economic, social and sanitary conditions that are unimaginable for a European citizen.

Africa's population is dynamically increasing. According to UN projections, the continent's current population of 1.5 billion can grow to 2.5 billion in 2050, and it may reach 4.3 or even 5.3 billion by 2100 !

\section{What are the causes of migration in Asia?}

Migration originating in Asia has two distinct causes: chaos and uncertainty induced by armed conflicts and population explosion. A part of the population decimated, tortured and exhausted by armed conflicts, wars and terror attacks in Afghanistan, Iraq and Syria flee their home region in the hope of survival and a chance to start a new life. By contrast, migrants fleeing, for example, Pakistan or Bangladesh are usually driven by tensions that derive from overpopulation.

Therefore migrants depart for Europe from both directions - obviously in an "organized manner." Organization is carried out by human smugglers. Now we can know from personal interviews that smuggling a migrant from Bangladesh to the Mediterranean or from Nigeria to the Libyan coast costs about USD 4,000-5,000. This is somehow paid by the migrants or their families. Thus we can also know that those who reach the gates of Europe are usually not the poorest but people who are able to pay such a significant sum to smugglers. At the coast smugglers make them board large rubber dinghies which are then pushed in the water. From the sea these migrants are rescued by either the ships of well-funded NGOs or the coast guards of Southern European states - thus they can arrive at the European continent.

In today's world of the Internet people living in an Afghan village or an African town can follow the life of the "rich West," and their relatives who had already settled there may as well continue to inform them about their everyday life. The two worlds are not isolated, although the distance between them is great. Since communication is possible, those who remained at home may have the illusion that they too can reach the other world. 


\section{Migration as a political and legal issue}

Since 2015 the phenomenon of migration gained a peculiar political emphasis, becoming one of the loudest themes of debates in European politics. While Western European, primarily leftist and liberal, political groupings hold that the only right and acceptable political and social behaviour is to take, unconditionally, masses of migrants who arrived at Europe in a way described above - illegally, relying on the services of smugglers, most politicians and societies of Central European countries reject this uncontrolled and massive immigration. None of the various fora of the European Union, the European Parliament or other bodies address the problem of migration through a reasonable and exploratory dialogue, while accusations and stigmatization are quite frequent. Hence, it is by no means superfluous to review the most important effective EU agreements on border crossing, immigration and migration as well the obligations of Member States therein.

The Schengen acquis is the body of EU norms, regulations, guidelines, implementation rules and common, harmonized "best practices" which regulate cooperation between states participating in the agreement on the abolition of internal borders and the parallel strict control of external borders. Its key elements are the Schengen Agreement which created the Schengen Area, the Schengen Convention implementing the Agreement, the Schengen Borders Code, the Schengen (Community) Visa Code, and Council Regulation (EC) No. $539 / 2001$ listing the third countries whose nationals must be in possession of visas when crossing the external borders and those whose nationals are exempt from that requirement. The "Schengen acquis" consists the common rules concerning the abolition of internal borders, ensuring free movement within the Schengen Area and, in order to defend this internal area through efficient and consistent border control, common rules for border surveillance, visa checks and data management and exchange necessary for sharing up-todate information. To this end, Member States created the Schengen Information System (SIS).

Based on the Schengen Agreement - which was incorporated into the main body of EU law by the 1997 Amsterdam Treaty - a new set of rules regulating cooperation between Member States had been established, including

1. removal of checks on persons at the internal borders;

2. a common set of rules applicable to persons crossing the EU's external borders;

3. harmonization of conditions for entry and the rules of issuing short-stay visa;

4. enhanced police cooperation, including rules applicable to cross-border surveillance and pursuit;

5. stronger judicial cooperation through a faster extradition system and transfer of enforcement of judgments; and

6. establishment of the Schengen Information System.

Regulation (EC) No. 562/2006 of the European Parliament and of the Council ${ }^{3}$ established the Schengen Borders Code. This law states that external borders may be crossed only at border crossing points and during their fixed opening hours. On entry and exit, third

3 "Regulation (EC) No. 562/2006 of the European Parliament and of the Council of 15 March 2006," Official Journal of the European Union L 105, 13.4.2006, 1-32. 
country nationals shall be subject to thorough checks. During these checks the fulfilment of entry conditions is verified through the Visa Information System (VIS). Third-country nationals should

1. be in possession of a valid travel document;

2. be in possession of a valid visa, if necessary;

3. justify the purpose of the intended stay and have sufficient means of subsistence;

4. not be persons for whom an alert has been issued in the Schengen Information System (SIS) for the purposes of refusing entry;

5. not be considered a threat to public policy, internal security, public health or the international relations of any of the Member States.

Regulation (EC) No. 810/2009 of the European Parliament and of the Council of 13 July 2009 establishing a Community Code on Visas (Visa Code), modified several times, can be considered a set of provisions on implementing the common EU/Schengen visa policy. It defines the common, uniform rules of issuing visas by Member States' consulates, determining the Member State and its respective consulate competent for examining and deciding on visa applications, as well as types of visa, requirements relating to the content and structure of application forms to be used, procedures and guarantees of deciding on applications, local and central cooperation and the exchange of data between Member States.

The issue of asylum is primarily discussed in Council Regulation (EC) No. 343/2003, the socalled "Dublin II Regulation." Among others, this regulation states that if an asylum seeker has irregularly crossed the border into a Member State, then the Member State thus entered shall be responsible for examining the application for asylum. Only one Member State can be designated as responsible for examining the application for asylum.

The Schengen acquis, that is, the system of laws applicable to the Schengen Area, properly regulates the administration of entry to or exit from the Area, and the procedures to be followed in the case of so-called third-country nationals. It also enforces an adequate security system, protecting the interests of Member States and their citizens and preventing illegal entry. In the framework of this system, cooperation and consultation between Members States, allowed by the Visa Code, is an "up-to-date" cooperation.

In 2015 a huge rift was opened on this seal-tight and effective system, developed at a considerable cost, when German Chancellor Angela Merkel declared that, under the sign of Willkommenskultur, Germany would take every refugee without checks and screening. As a result of this gesture, hundreds of thousands of alien citizens entered the Schengen Area whose identity remained unchecked, had no travel documents, and no prior data on them were available. Since then, much information and misinformation has been circulating about the success or failure of the arrivals' integration, terror attacks and their explanations.

The legal aspect of this problem is a grave issue. The German Chancellor made her decision without any prior negotiation, and also neglected all of the related EU treaties, listed above, which regulate entry into the Schengen Area. We can conclude that her decision was made in opposition to EU regulations, that is, it ran counter to effective laws. It reflects well the relationships prevailing within the Union that no EU institution put this question, that is, the lawfulness or unlawfulness of allowing masses of migrants to enter, 
on its agenda. By contrast, the press and the political arena resounded the question of how the burden of these masses should be distributed among member states, that is, the issue of so-called migrant quotas.

Central European countries unanimously resist this pressure, rejecting, based on principle, the attempt to exclude some countries from decision-making, while they are expected to take their share of this burden.

\section{What is deceptive in the migration debate?}

The migration debate gave rise to numerous false, misleading thoughts and arguments, but the gravest among them rests on a false analogy. The politicians of Western European states frequently refer to the ungratefulness of Central European societies, saying that there was a time when they took Eastern European refugees, hundreds of thousands of Hungarians, Poles and Czechs, while now the same societies are not willing to take those in need.

This argumentation and analogy is misleading at a minimum of two points. First, Central European countries have been experiencing an influx of people from neighbouring areas for the last thirty years. Hundreds of thousands of immigrants from Ukraine, Russia, the Balkan countries and even from China arrived in this region with the intent to settle down and adapt. And most of them did manage to fit in. Second, the Central European refugees of the twentieth century had the same intent, to fit in Western European and American societies. They did not claim their rights but sought the opportunity of successful adaptation, strove to adopt the customs, culture and language of the host society, and to return, through their work, the generous gesture of reception. This behaviour fundamentally differed from the attitudes of African and Asian migrants, who now destroy their identification documents, lie to the authorities of receiving countries, have an alien culture and their intention to adapt is dubious.

There is nothing incomprehensible in the fact that Central European societies - which have never been colonizers, thus have no "live" contact with African and Asian societies - are afraid of masses of aliens arriving from these places. Having heard many alarming and horrifying news about terrorist actions and their innocent victims in the big cities of Western Europe as well as political "spins," the citizens of these countries tend to support domestic political leaders who promise firm protection and security in this respect.

For Central Europe, the migration question is a matter of security. These countries do not wish to turn into societies within which ethnic groups and masses with utterly different cultures and civilizations create their enclaves, which in turn facilitate the establishment of a society with a culture and civilization alien to those of Europe, enclaves that are impenetrable for the organs of state and local administration. Over the centuries - living at the eastern and south-eastern periphery of Europe - Central European societies protected, in the course of their different self-defence struggles, their European identity as well as their national identity because the two were essentially identical. For the peoples of Central Europe, European civilization made up of Greek culture, Roman law and Christianity provided a handle or support over centuries of resistance to Mongolian or Turk, Soviet or Nazi threat and occupation. This European identity has been constructed 
and reinforced by the best thinkers, artists and statesmen of the region. Therefore European identity is an organic part, rather than the opposite or supplement, of the identity of Central European peoples. Viewed from this perspective, the transformation of Western Europe's societies, the "metamorphosis" of the European value system, heavily guarded and often defended at the price of many lives, its weakening and deterioration do not seem to be an attractive outlook for the peoples of this region.

The strand of thought presented by some authers, namely, a possible way of integrating Muslim communities, raises the particular question of the state's internal sovereignty. Analyzing the nature of Western, secular "society" and traditional Islamic "community," some authors conclude that we should acknowledge, accept the practice that derives from Islamic communities existing in Western European societies, namely, that they settle their legal controversies within their own community, governed by the fundamental principles of Islam, rather than in the framework of the rule of law and institutions of the host state.

As it is known, Islam is a religion, civilization, cultural community, way of life and legal order at the same time. It is a societal order where individuals can be understood only as members of a certain community - the family, which means that they can live only in complete dependence of the family. The Church or religion and the state have not been separated, and only a religion-based legal institution, shariah exists. As far as Western European societies and states accept that Islamic communities settle legal controversies within their own framework, certain areas of the state and society, certain communities being exempt from the jurisdiction of the host state and its authorities, they also accept that the internal sovereignty of the modern state of law is violated and that unlimited internal sovereignty ceases to exist. If we try to envision the outcome of this problem, then we can easily face alarming prospects!

If the political and administrative system of the European Union would function in line with its mission, it had launched an open, structured and considerate debate on the migrant question that has evolved since 2015, the application or breach of the regulations described above, the societal consequences of such breach, the mode of making decisions on this issue, the possibilities and political, moral, financial, security and other conditions of sharing this burden.

Whenever we speak about the security of Europe - and Central Europe, we cannot avoid the question of migration and its reasonable rather than emotional discussion in relation to security.

\section{Central Europe's geopolitical determination}

In a geopolitical sense - and in terms of its historical experiences - Central Europe is located within the Berlin-Moscow-Istanbul triangle, which is an unalterable status. However, in a political sense these three reference points are at different distances from us. Berlin is an ally and our biggest, key economic partner. It is in our interest to have good partnership relations with Moscow, but we must be aware that Russian politics has always been - and will be - driven by imperial interest. As a NATO member, Turkey is also our ally, but the steps it took in recent years, in both domestic and foreign policies, were by no 
means evidence of a friendly attitude towards and the commitment of an ally to the West. Turkey begins to emerge as one of the leading countries of the Islamic world, gradually leaving behind the domestic policy of a secular state, strictly separated from the Islamic Church, and the West-friendly foreign policy position and road designated by Mustafa Kemal Atatürk.

Therefore Central Europe - forming the eastmost part of the European Union-borders all the eastern and south-eastern regions which carry security risks. The wave of migrants from the south and south-east keeps these regions, Greece and her northern neighbours - Bulgaria, Romania, North Macedonia, Serbia, Hungary and Croatia - under constant pressure. So far - in the last four years - neither the individual member states, nor the institutions of the European Union showed much activity aimed at resolving the Middle Eastern crisis or managing the evolved migration situation. They abandoned Turkey, Greece and the rest of states in the region to cope with this problem alone. In fact, they poured political criticism on Central European politicians who identified the defence of Europe's external borders as a common task and obligation, with reference to the acquis cited above. They did this despite the fact that the intensification of the migration tension may give rise to a serious security and political crisis in the south-eastern borderlands of the Union, from the boundaries of Hungary and Croatia down to the Aegean Sea.

Another grave risk factor is the Union's eastern borderland, that is, the region next to the eastern boundary of the Baltics, Poland, Slovakia, Hungary and Romania. As geopolitical factors, Russia, Ukraine and Belarus are not the carriers of democratic stability.

As a both regional and global player, Russia induces enduring worries in her neighbours. The occupation of Crimea and Eastern Ukraine, continued exertion of political and military pressure on Baltic states, imposing direct threat on Poland an Lithuania through the remilitarization of the exclave called the "Kaliningrad Region," the re-incorporation of the ominous symbols of communism into state symbolism, the resuscitation of the cult of Stalin - these are all signs which understandably generate concerns in the countries and societies of the region.

Although Central Europe's geopolitical position cannot be changed, common European and Euro-Atlantic security safeguards may guarantee defence in this position.

\section{References}

BÁBA, Iván: The Fall of Communism: Changing the Regimes in Central Europe in 19891990. Köszeg, iASK, 2016. [Published in Hungarian as A kommunizmus bukása Rendszerváltoztatás Közép-Európában 1989-1990-ben], Kőszeg, iASK, 2017.

Central European Futures: Five Scenarios for 2025. Visegrad Insight Special Edition 1 (12). Warsaw: Res Publica Foundation, 2018. Č́́ŽlK, Tomáš - BORÁROSOVÁ, Ingrid (eds.): The Future Revolutions in Central and Eastern Europe, Bratislava, Centre for European and North Atlantic Affairs, 2018. 
$\mathrm{HROCH}$, Miroslav: Das Europa der Nationen: Die moderne Nationsbildung im europäischen Vergleich, Göttingen, Vandenhoeck \& Ruprecht, 2005.

KISS, Csaba Gy: Understanding Central Europe: Nations and Stereotypes, Budapest, Nap 2013.

KUČERA, Rudolf: Kapitoly z dějín Střední Evropy, Praha, ISE 1992.

KUNDERA, Milan: "Un occident kidnappé ou la tragédie de l'Europe centrale." Le Débat 1983/5, 27, 3-23. Published in English as "The Tragedy of Central Europe." Translated by Edmund White. New York Review of Books, 31, 7 (April 26, 1984), 33-38.

MARUŠIAK, Juraj, et al. Is Visegrad Still a Central European "Trade Mark"? Bratislava, VEDA, 2013.

Searching for synergies: V4, TSI and other formats of regional cooperation in Central Europe. A long-term analysis by the "Think Visegrad" V4 Think-Tank Platform, November 2019.

SZÜCS, Jenő. "Three Historical Regions of Europe: An Outline", in: Civil Society and the State. Edited by KEANE, John, London, Verso Books, 1988, 291-332.

Understanding Central Europe: Edited by MOSKALEWICZ, Marcin - PRZYBYLSKI, Wojciech, London/New York Routledge, 2018

Višegradská pamět či višegradské paměti? (Pamět většiny i paměti menšín). Edited by OLSAKOVÁ, Doubravka - KAISEROVÁ, Kristina, Ústí nad Labem: FF UJEP, 2014.

WOLF, Larry: Inventing Eastern Europe: The Map of Civilization on the Mind of the Enlightenment. Stanford, CA, Stanford University Press, 1994.

\section{Author}

Prof. Iván Bába PhD

Felsőbbfokú Tanulmányok Intézete Institute of Advanced Studies, Kőszeg

H - 9730 Köszeg, Chernel u. 14., Hungary

ivan.baba@iask.hu 